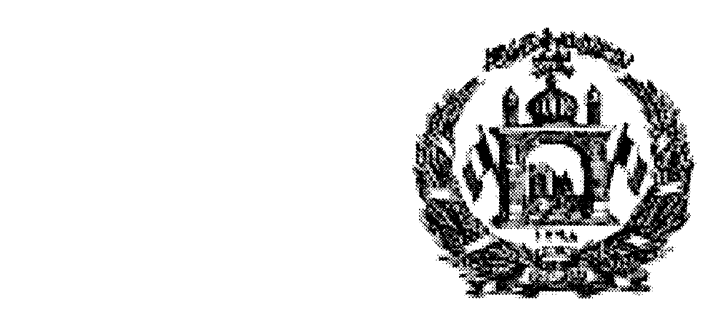

\title{
Islamic Republic of Afghanistan
}

\section{Brief BIOGRAPHIES}

\section{Of The New Cabinet Members}

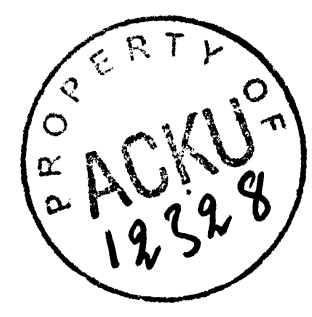

Office of the Spokesperson of the President

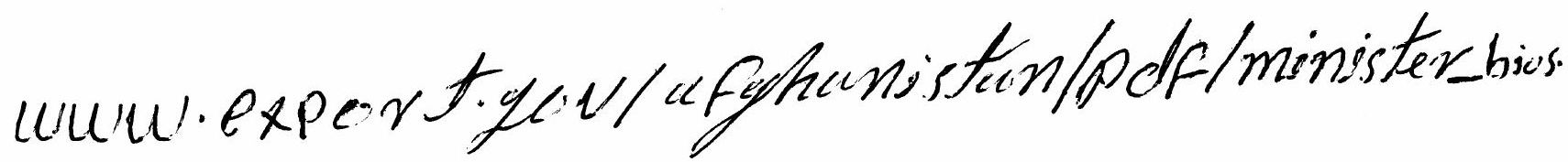




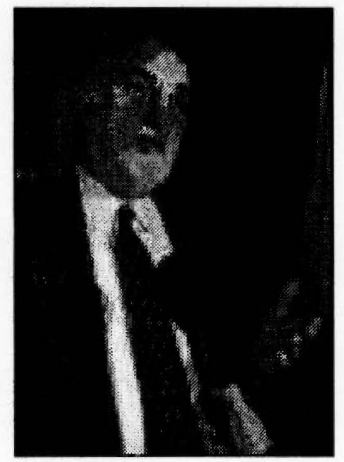

H.E. Hedayat Amin Arsala was born in 1942. After receiving his high school diploma, he continued his education in the field of Economics and pursued his $\mathrm{PhD}$ in the United States.

In 1969, he started his professional career at the World Bank Youth Professional Program and served at various positions with the World Bank. In 1987, he left the World Bank and joined the Afghan resistance against the Red Army and served as Senior Advisor and member of the Afghan Mujahideen Unity Council. He was also an active member of the resistance against the Red Army until 1989.

From 1989 to 1992, he served as the Minister of Finance of the Transitional Government of Afghanistan. In 1993, he was appointed as the Foreign Minister of Afghanistan.

H.E. Dr. Arsala is one of the pioneers of calling for the Loya Jirga in Afghanistan. In 1998, he was the member of Executive Council of Afghan Loya Jirga representing the former Afghan King His Majesty Zaher Shah, the Father of the Nation. He also had a major role in convening the Bonn Conference in December 2001, which led to the establishment of the Afghan Interim Administration where he served as a Vice Chairman and the Finance Minister.

After the Emergency Loya Jirga in 2002, he served as the Vice President of the Transitional Islamic State of Afghanistan, as well as the Chairman of the Independent Civil Services Administrative Reform Commission. He also served as advisor to the Central Statistics Office of Afghanistan, the Afghan Economical Cooperation Committee, and as a member of the National Security Council of Afghanistan. He has represented Afghanistan on many official trips outside Afghanistan.

H.E. Dr. Arsala is fluent in Pashto, Dari and English. 


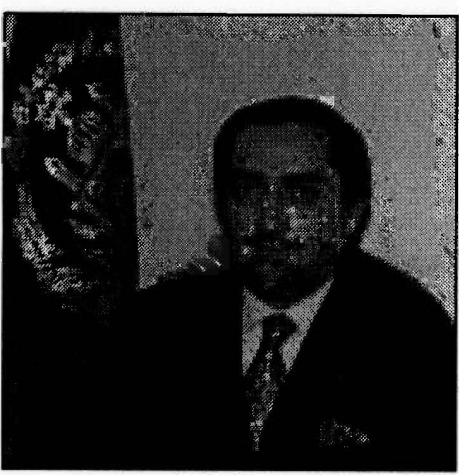

H.E. Dr. Abdullah Abdullah, son of Ghulam Mahyyod- Din Zmaryalay (Senator of the last period of Parliament) was born in 1960 in a religious family in Kabul. H.E. Dr. Abdullah graduated from Naderia High School in 1976 and went on to study ophthalmology at Kabul University's Department of Medicine where he received an M.D. degree in 1983. After receiving his degree, H.E. Dr. Abdullah served as the Resident Ophthalmologist at Noor Eye Institute in Kabul until 1985.

From 1985 to 1986 he worked in the Ophthalmology Hospital for Afghan Refugees in Peshawar, Pakistan and was also the Director of Healthcare for the Resistance Front. In 1986, Dr. Abdullah became the Special Advisor and Chief Assistant to Commander Ahmad Shah Masood, a distinguished figure in the Afghan resistance to the Soviet Occupation and the Taliban rule of the country, and served in that capacity until 1992.

Following his service with Commander Masood, Dr. Abdullah served as the Director General in the Ministry of Defense in Kabul from 1993 until 1996.

During the years of 1996 to 2001, he served as the Deputy Foreign Minister and spokesperson for the Islamic State of Afghanistan. He became Foreign Minister in 1998. On December 22, 2001, during the Bonn Intra-Afghan talks, Dr. Abdullah was selected as the Minister of Foreign Affairs for the Interim Administration of Afghanistan under then Chairman Hamid Karzai. In June of 2002, Dr. Abdullah was again confirmed as the Minister of Foreign Affairs by the national Loya Jirga, which was comprised of 1,501 selected officials from across the country.

H.E. Dr. Abdullah is fluent in Dari, Pashto and English and also knows Arabic and French.

\section{His Excellency General Abdü Raheem Wardak Minister of Defense}

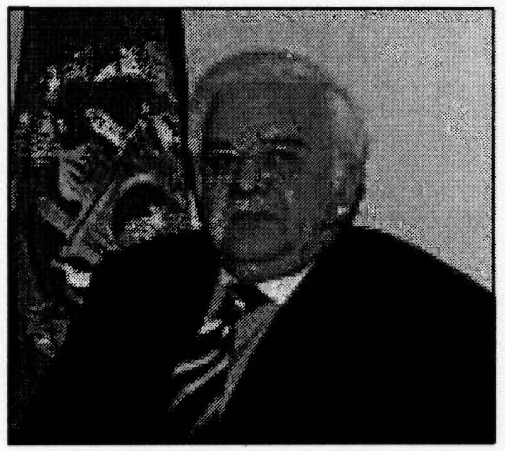

H.E. General Abdul Raheem Wardak, son of Abdul Ghani, was born in Wardak Province in 1940. After graduating from Habibia High School, he joined the Cadet University. He completed further studies in the United States and Ali Naser Academy in Cairo, Egypt.

He has served as a Lecturer in Cadet University and Assistant of Protocol of the Ministry of Defense. He served as the military assistant of Muhaz-e-Milli, was the military assistant of the TriLateral Unity, a member of Itehad-e-Mujahiddin, and commander of the Jihadi fronts of Muhaz-e-Milli. After the fall of communist regime, he was a member of the Security Committee of Kabul City, Chief of the Army Staff, Director of the Military Officers Society, Director of the Education Commission, member of the National Army Commission, Deputy Defense Minister, Director of Disarmament Program and Director of Reform of the National Army.

He has many literal works in Pashto, Dari and English. 

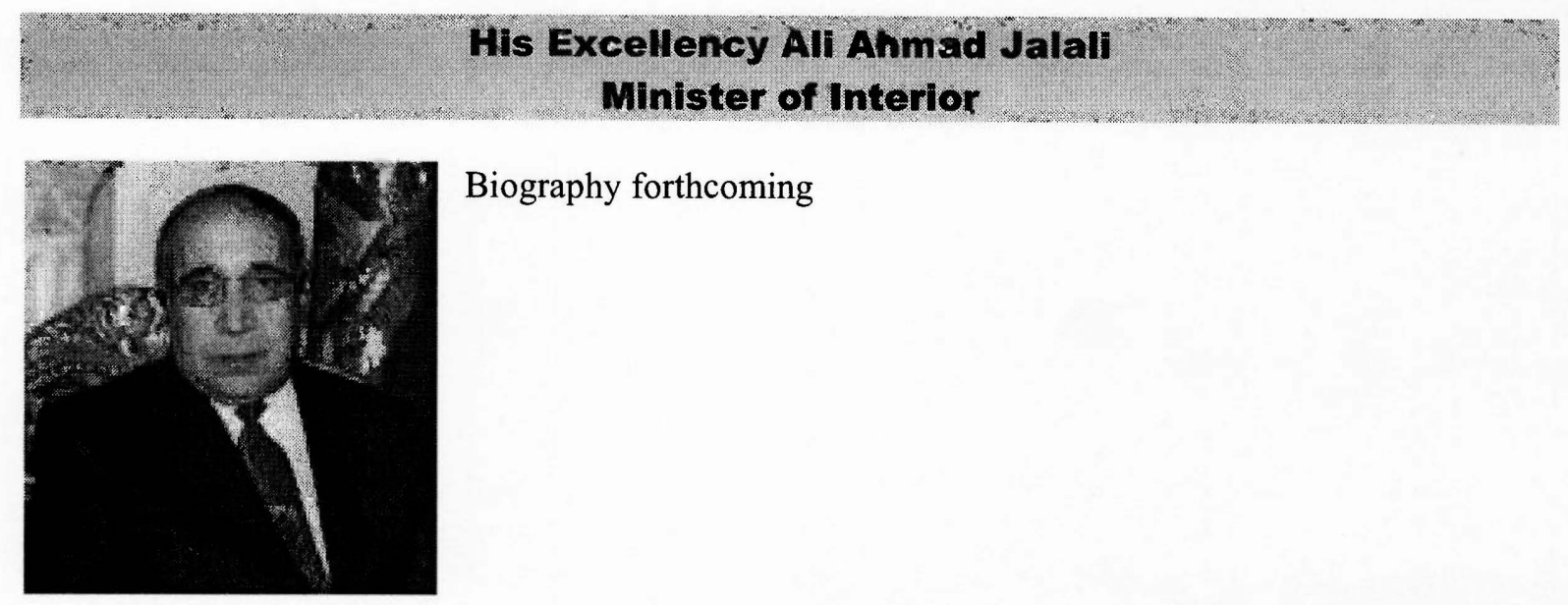

Biography forthcoming
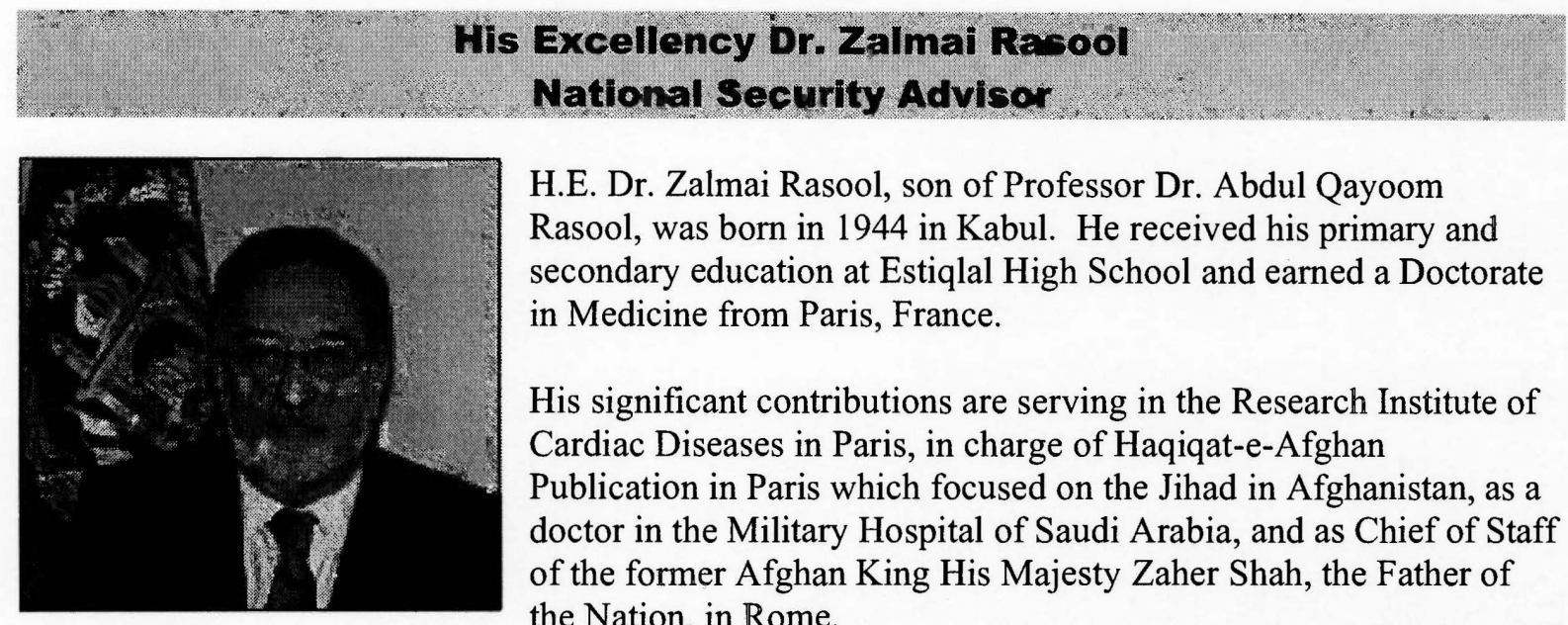

H.E. Dr. Zalmai Rasool, son of Professor Dr. Abdul Qayoom Rasool, was born in 1944 in Kabul. He received his primary and secondary education at Estiqlal High School and earned a Doctorate in Medicine from Paris, France.

His significant contributions are serving in the Research Institute of Cardiac Diseases in Paris, in charge of Haqiqat-e-Afghan Publication in Paris which focused on the Jihad in Afghanistan, as a doctor in the Military Hospital of Saudi Arabia, and as Chief of Staff of the former Afghan King His Majesty Zaher Shah, the Father of the Nation, in Rome.

H.E. Dr. Rasool served as a Minister of Civil Aviation and Tourism during the Interim Government and as a National Security Advisor during the Transitional Islamic State of Afghanistan.

H.E. Dr. Rasool is fluent in Pashto, Dari, English, French, Italian and Arabic. He has authored thirty medical books, booklets and other publications in Europe and the United States. 


\section{His Excellency Noor Mohammad Qarqeen Minister of Education}

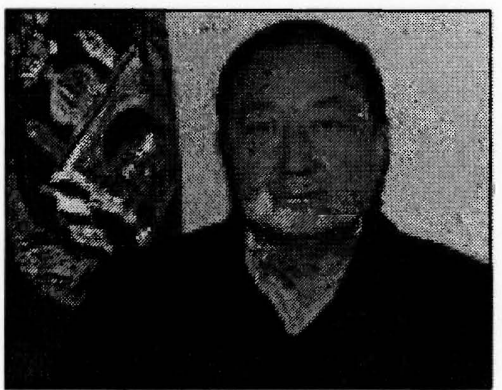

H.E. Noor Mohammad Qarqeen, son of Haji Mohammad Qul, was born in 1953 in Tepa in the Qarqeen District of Jozjan Province. After completing primary school in Qarqeen, he was admitted to Habibia High School in Kabul. He then was admitted to the Law Faculty of Kabul University in 1972, where he earned his Bachelor's Degree.

In 1978, he began service in the Ministry of Education as a member of the Uzbek and Turkmen Department.

He has also worked as the Director of Silo of Balkh and Director of Gas of Hairatan. After the Soviet invasion, he migrated to Pakistan and took part in Jihad against the Soviet Union. He was a member of Loya Jirgas and National Councils during different Periods.

In 2001, he was appointed as Minister of Labor and Social Affairs. He resigned from his post in September of 2004 to serve as the Director of the electoral campaign of H.E Hamid Karzai.
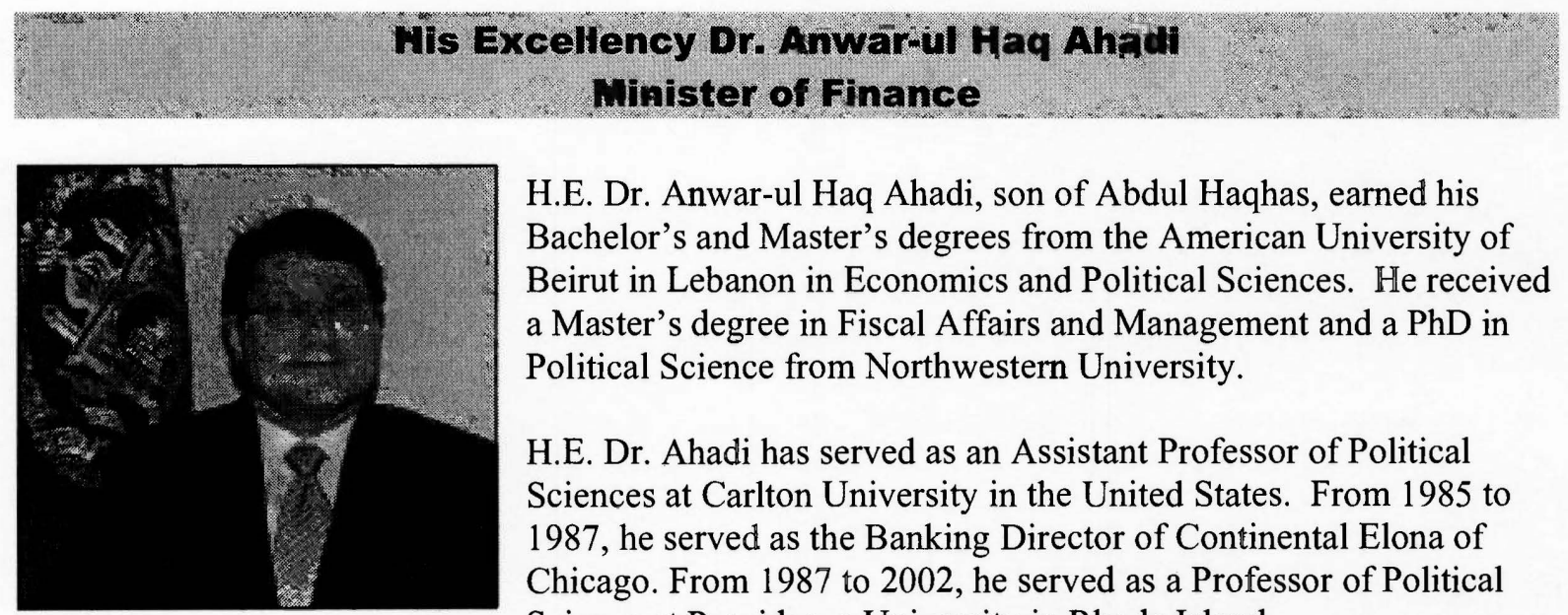

H.E. Dr. Anwar-ul Haq Ahadi, son of Abdul Haqhas, earned his Bachelor's and Master's degrees from the American University of Beirut in Lebanon in Economics and Political Sciences. He received a Master's degree in Fiscal Affairs and Management and a $\mathrm{PhD}$ in Political Science from Northwestern University.

H.E. Dr. Ahadi has served as an Assistant Professor of Political Sciences at Carlton University in the United States. From 1985 to 1987, he served as the Banking Director of Continental Elona of Chicago. From 1987 to 2002, he served as a Professor of Political Science at Providence University in Rhode Island.

From 2002 to 2004, he served as the Director of Da Afghanistan Bank (Central Bank of Afghanistan).

H.E. Dr. Ahadi has written many publications in academic journals, books and popular dailies of the United States and speaks Pashto, Dari and English. 


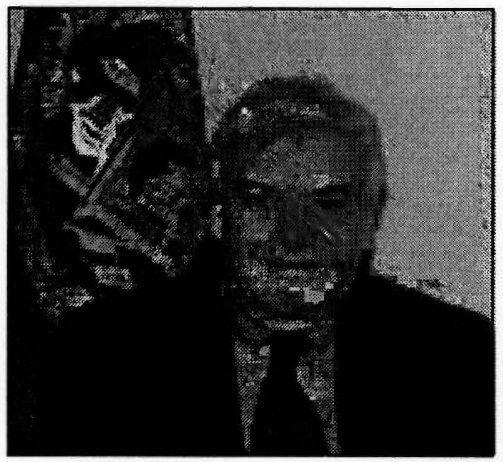

H.E. Dr. Mir Mohammad Amin Farhang, son of Mir Mohammad Sediq Farhang, was born in and educated family in Kabul in the year 1940.

He graduated from Esteqlal High School in 1959 and earned a Bachelors Degree in Economics from Kabul University. He earned a Masters Degree and a Doctorate Degree in Economic Development from Köln University in Germany.

From 1974 to 1978, he was a professor in the Economics Faculty of Kabul University and the Director of the National Economy Institute.

In 1978, he was imprisoned in Pul-e-Charkhi Jail and in 1982 after his release he went to Germany. In Germany, he served as a professor in Ruhr University and the coordinator of Afghanistan's Archive. After the fall of Taliban regime he was appointed as the Minister of Reconstruction.

He has published many articles in the field of economics and politics in the Afghan and international publications. He has fluency in Dari, Pashto, French, German, and English.

\section{His Excellency Alhaj Mohammad Ismael Minister of Eneroy and Water}

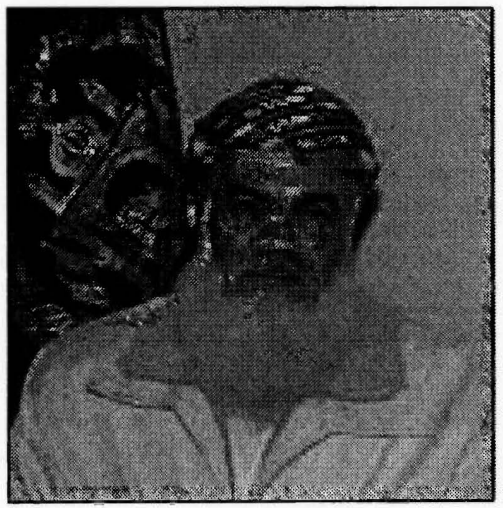

H.E. Alhaj Mohammad Ismael, son of Haji Mohammad Aslam, was born in 1948 in Naser Abad village of Shindand District of Heart. He completed his primary education in Waez Kashifi High School. In 1960, he was admitted to the 6th grade of Cadet School and earned his higher education from Cadet University in 1970. He joined Division Number 17 of the National Army in Herat and subsequently started Jihad as the division revolted against the Soviets.

In 1981, he served as the Ameer of the southwestern parts of the country. In 1990, after the formation of interim government, he acquired the military rank of a General and was appointed as the Governor and Commander of the Corps Number 4 of Herat Province.

In 1997, he was detained by the Taliban and spent three years in jail. After the fall of Taliban, he was appointed as the Governor of Herat and Commander of the Corps Number 6.

H.E. Ismael Khan knows Dari, Pashto and English. 


\section{His Excellency Dr. Enayatullah Qasimi Minister of Transportation}

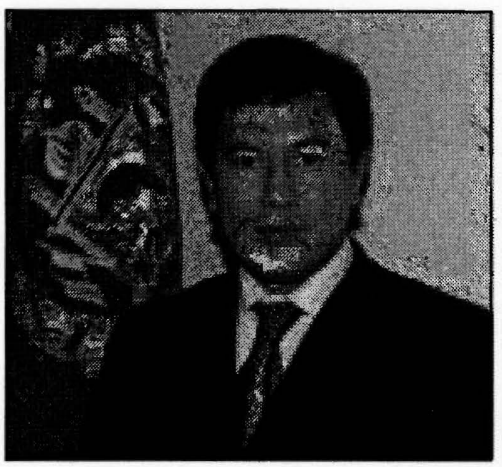

H.E. Dr. Enayatullah Qasimi, son of Ahmad Ali Qasimi, was born in Kabul. He completed his primary education in Karteh Lagaan School of Lashkargah City in Helmand Province. He continued his secondary education, religious studies and languages privately in Pakistan. During his studies, he worked with organizations like IRC and Nebraska University.

H.E. Dr. Qasimi graduated from Lornswel School of New Jersey in the United States in 1996. He earned his Bachelors in Economics from Bord University in the United States. In 2001, he received his Masters in Management and Commerce from the University of Baltimore in the United States. He also earned his Juris Doctorate from the law faculty of the University of Maryland in 2001.

H.E. Dr. Qasimi worked as an associate at a Baltimore law firm and worked on international legal affairs worked with the International Non-Profit Law Center in Washington, D.C. He served as the Legal and International Affairs Advisor to President Karzai during the Transitional period.

\section{His Excelleney Amir Zai Sangeen Ministor of Communicatious}

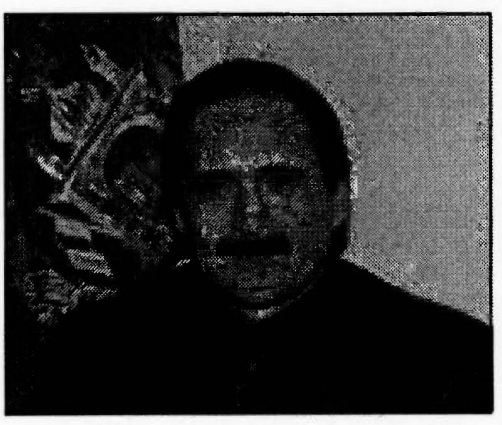

H.E. Amir Zai Sangeen, son of Amir Gul Shah Khail, was born in the Urgoon District of Paktika Province. He completed his primary education in Urgoon and secondary education in Gardez and graduated from the Communication Training Center. In 1972, he earned a Bachelor's degree in Electronics and Communications from Southern London University of the UK.

He started his professional career as a teacher in the Communication Training Center and from 1978 to 1980 and later served as the director of that center.

In 1980, he migrated to Sweden and became one of the founding members of Swedish Committee in Afghanistan. He actively participated in the development of the Swedish Committee for Afghanistan, which has had an outstanding role in promoting education, agriculture and health throughout the past 25 years in Afghanistan.

H.E. Mr. Sangeen was employed in the communications sector in Sweden and served as a team member of the communication project of Shah Khalid in Saudi Arabia.

After 2001, H.E. Mr. Sangeen repatriated to Afghanistan. He has held training seminars for the engineers of the Ministry of Communication and Afghan Wireless Company. He was the leader of the Supervising Committee of the GSM license, and a Senior Advisor to the Minister of Communication from February 2003 till his appointment.

H.E. Mr. Sangeen was appointed as the Director of Afghan TeleCom in July 2004 and had an effective role in formation of the company, approval of the statute, and follow up of the communications 
projects. He was also in charge of creating a structure for Afghan TeleCom and interconnection where he developed new procedures in this field.

\section{His Excellency Dr. Mir Mohammad Sediq Minister of Mines and industries}

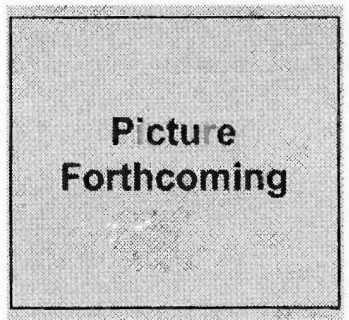

H.E. Mir Mohammad Sediq, son of Mir Ghulam Sakhi, was born in 1945 in Sheikhan of Mirbacha Kot District of Kabul. After primary and secondary education in Kabul, he earned a Bachelors Degree in Engineering and a $\mathrm{PhD}$ from American University in the United States.

$\mathrm{He}$ is a member of American Engineers Unity and has served in Afghanistan, Pakistan, Yemen, Ethiopia, Kenya, Somalia, Puerto Rico and the United States. From 1975 until now, he has been working in the engineering field.

He speaks Dari, Pashto, English and Urdu.
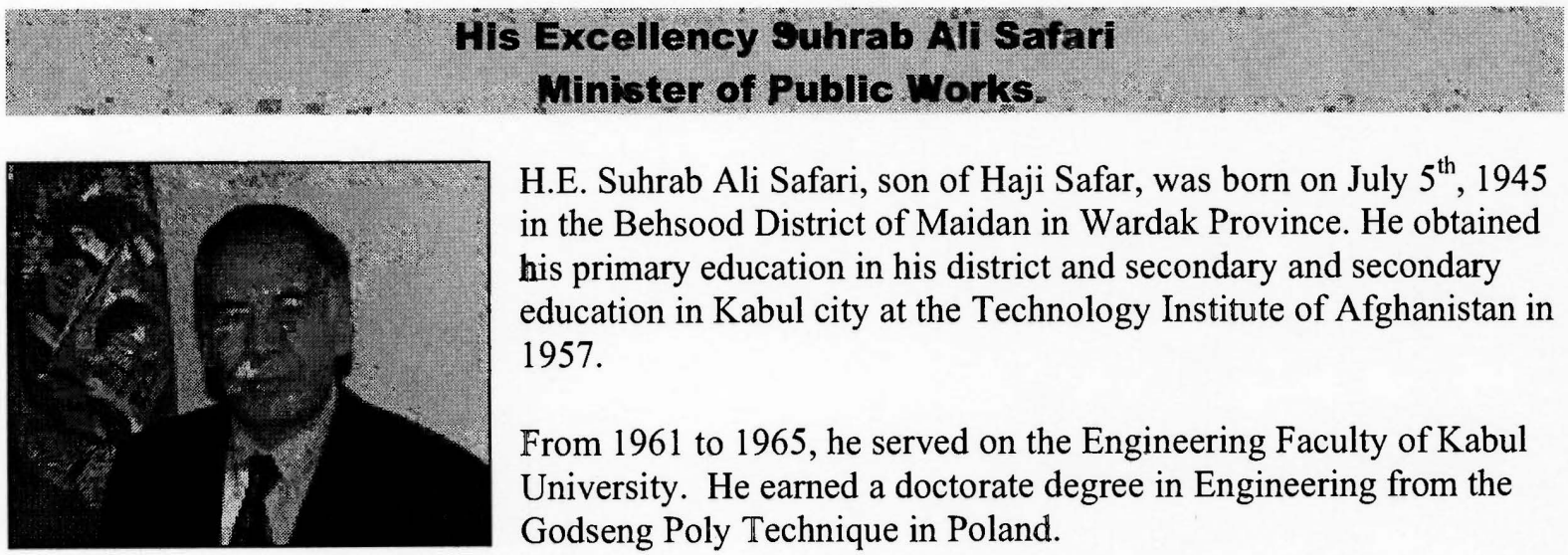

H.E. Suhrab Ali Safari, son of Haji Safar, was born on July $5^{\text {th }}, 1945$ in the Behsood District of Maidan in Wardak Province. He obtained his primary education in his district and secondary and secondary education in Kabul city at the Technology Institute of Afghanistan in 1957.

From 1961 to 1965 , he served on the Engineering Faculty of Kabul University. He earned a doctorate degree in Engineering from the Godseng Poly Technique in Poland.

H.E. Suhrab Ali Safari is fluent in Dari, Pashto, English and Polish and knows a little German.

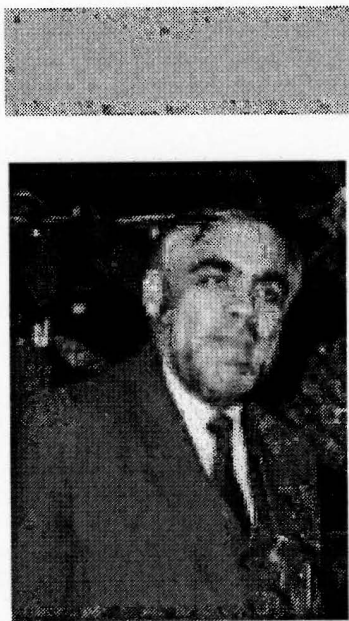

\section{His Excellency Yusof Pashtun Minister of Urban Development}

Biography forthcoming 


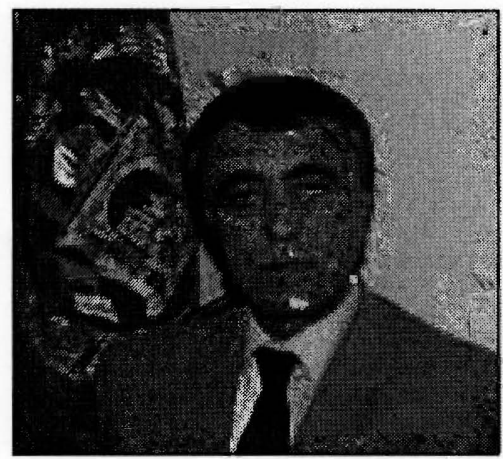

H.E. Obaidullah Rameen was born in 1952 in Baghlan Province. He was a student of Khost and Fereng High School for Primary and Secondary Education and graduated from Baghlan High School. He earned his Bachelors Degree from Kabul University in 1976 and studied for a year at the Agriculture Promotion Bank.

He was an inspector at the Agricultural Bank from 1975 to 1977, a Director of the Banks' Cooperative from 1981 to 1983 and a Director in the Agriculture Promotion Bank from 2001 to 2004.

He was also the Director of Center of Traders and Craft workers nongovernmental NGO and the acting Director of Agricultural Unity of Afghanistan.

\section{His Excellency Sarwar Dahish} Minister of Justice

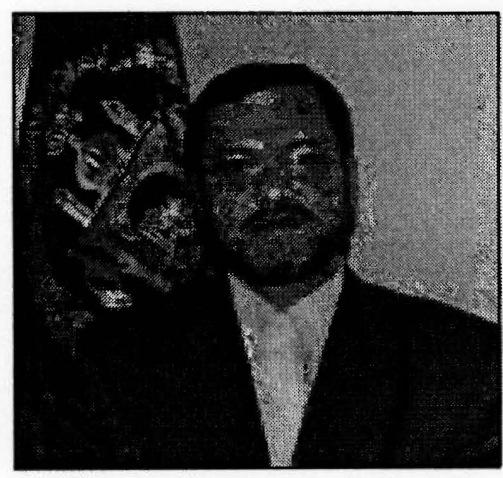

H.E. Sarwar Danish, son of Mohammad Ali, was born in a religious family in 1951 in Daikundi Province. He completed his primary education in Afghanistan and completed his higher education in Iraq, Syria and Iran.

He has earned a Bachelors Degree in Law, a Certificate in journalism, a Bachelors Degree in Islamic Culture and Education, a Masters Degree in Islamic Fiqh and is working on a $\mathrm{PhD}$ (in progress) in the same field.

Fifteen different books have comprised the result of the academic work of H.E. Mr. Danish, some 700 hundred of his essays have also been published. From 1982 until 2001 , he had been the in charge of different publications.

He was a member and active participant in the Emergency Loya Jirga of 2002, a member of the Constitutional Drafting Commission through a decree by H.E. President Karzai, a participant in the Constitutional Loya Jirga.

When Daikundi was announced as a province early this year, he was appointed as the first Governor. 


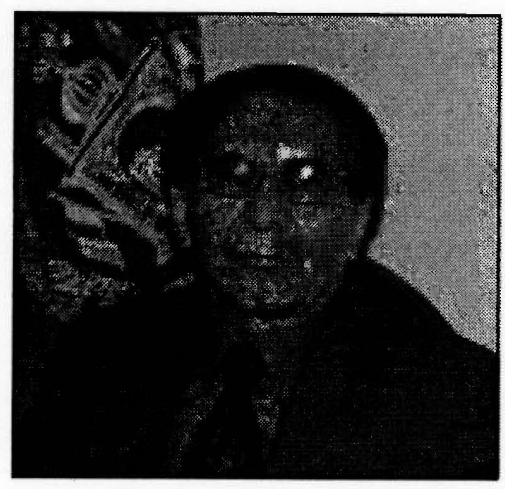

H.E. Dr. Ameer Shah Hasanyaar, son of Ghula Hasan, was born in the Panjab District of Bamyan province in 1940. He has finished secondary and higher secondary education at Ibn Seena and Agriculture School in Kabul, Afghanistan. He earned his Bachelors Degree from Kabul Agricultural University, a Masters in Ecology from the University of New York, United States, and a Doctorate in Agriculture from Colorado University, United States.

From 1965 to 1972, he served as a Lecturer in the Education Faculty of Kabul University. From 1972 until 1992, he served as Lecturer in the Agriculture Faculty of Kabul University. From 1992 until 1996, he was the Director of Kabul University. He is the author of eight textbooks and has published many research articles.

He is a member of Educational Council of Kabul University and Grand Council of Protecting Islamic System in Afghanistan. He is also a member of the Cultural Council of the Ministry of Information and Culture.

\section{His Excellency Dr. Sayed Makhdoom Raheen Ministry of Information and Culture}

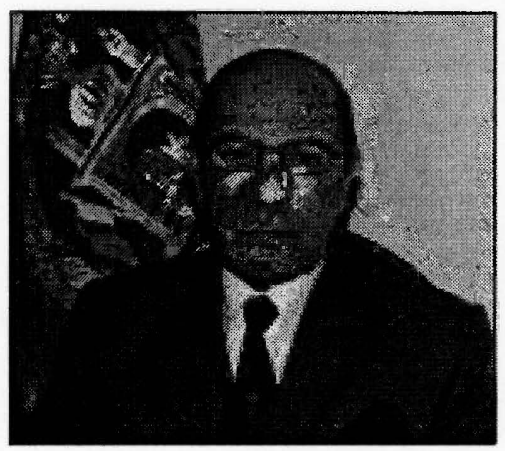

H.E. Dr. Sayed Makhdoom Raheen was born in 1946 in Kabul city. After receiving a bachelor's degree in Afghanistan, he received his Masters and PhD from Tehran University in 1973.

Upon return, he served as a lecturer at Kabul University and a director of Arts and Culture of the Ministry of Information and Culture.

H.E. Dr. Raheen was one of the members of the drafting of the constitution during the presidency of Daud Khan and participated in the Loya Jirga of 1977. After the Soviet invasion, he migrated to Pakistan and made endeavors for the unity of the Mujahedin. After the foundation of Islamic Unity of Afghanistan- made of moderate parties- he was a member of the High Council and the Director of Cultural Committee.

A poet and popular writer, H.E. Dr. Raheen has carried out many research projects in the field of culture, literature, history and Islamic Orders. He has written many essays, which have been published. His books, that have focused on Sayed Jamaluddin Afghani, Ameer Khosrow Dehlawai and Relation of Afghanistan in Subcontinent from Past times to the Seventh Century.

His works during the Jihad include Ashk e Khurassan, Aza Daran, Responding to Khalili and Today's Muslim (Pashto), which were all published.

In 1988, he led the National Islamic Movement with other scholars and Jihadi commanders. He founded the Peace and Democracy Association for Afghanistan with the assistance of Afghan intellectuals in 1991 and served as the Director of the organization. 
In 1998, he was accepted as a member of the executive committee of the Loya Jirga in Rome and participated in all the activities concerning Loya Jirga until the Bonn conference was held in 2002 . He visited Afghanistan, Uzbekistan, Iran and Tajikistan to explain the objective of the emergency Loya Jirga.

He was appointed as the Minister of Information and Culture during the interim Administration. He was also elected as the Director of the Council of Kabul residents in September 2003. H.E. Dr. Raheen was awarded a Medal of Freedom of Expression and Culture by the former Afghan King, His Majesty Zaher Shah, the Father of the Nation.

\section{His Excellency Mohammad Amin Fatemi} Minister of Public Heakh

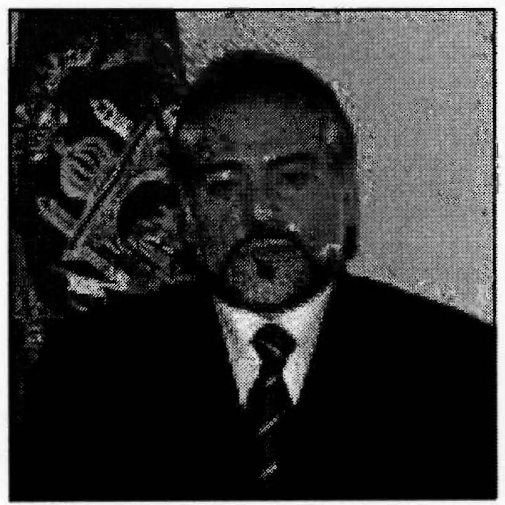

H.E. Dr. Mohammad Amin Fatemi was born on 1952 in Ningarhar Province. He graduated from Habibia High School and earned his Doctorate in Medicine from Ningarhar Medical College in 1977. He has participated in advanced academic programs in Bonn, Germany and the High Institute of Public Management in Karachi. He has a certificate in health care and earned a Health Policy in Developing Countries certificate from Boston University the US in 1995.

H.E. Dr. Fatemi has served as a doctor in Badakhshan, as a teacher in the Kabul Public Health Institute and a member of the Health Awareness Department. He was in charge of the education program of IRC, founder and Director of Mujahedin's Unity Programs, member of the advisory board of the Health Ministry in the interim government in the early 1990's, and Deputy Minister and First Deputy of the Public Health Minister. He was the Public Health Minister from 1993 to 1995.

H.E. Dr. Fatemi has served as a advisor to the World Health Organization in Geneva, Switzerland for Mediterranean countries, as permanent advisor of the WHO for the Eastern Mediterranean countries, and from 1992 to 1994, a member of the Executive Board of WHO. From 1991 to 2001, he was a member of the Board of the Medical Services Development for Afghans, a member of the Board of the Ladies Hospital for Afghan Refugees, member of the "Order of Good Time" in Canada. He has participated in many academic conferences and is the author of Health Care, Right and Wrong Use of the Medicines, and First Aid. 


\section{His Excellency Nematullah Shahrawi \\ Minister of Haj and Islamic Affairs}

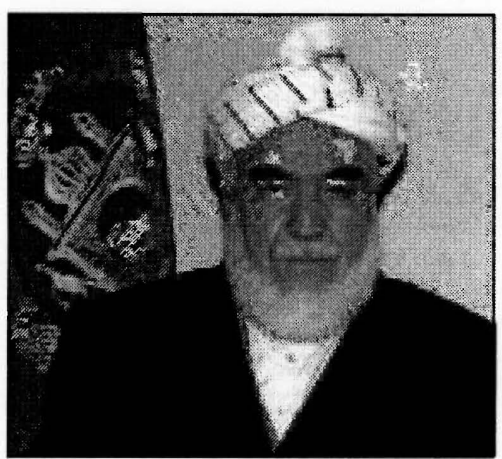

H.E. Nematullah Shahrani, son of Ebadullah Shahrani, was born in the Jerm district of Badakhshsan in a religious family. He completed his primary education in Badakhshan and graduted from Abu Hanifa School in 1960 . He was admitted to Faculty of Islamic Studies of Kabul University in the same year.

After earning his Bachelor's degree in 1964, he joined the university as a member of teaching committee. In 1967, he went to Egypt and earned a Master's Degree from Al-Azhar University.

In 1960, he again continued his services as a lecturer at Kabul University and was Chief Editor of Sharayat Magazine. In 1976, he went to the United States and studied law at George Washington University for a year and a half. He also went to the UK for a research trip and observed the courts, police stations, attorney's office, law institutes and centers. After the Soviet invasion, he was imprisoned for some time and went to Pakistan after he was released.

He has worked in some popular magazines of the country (Payam-e-Haq, Alfalah, Qaza, Urfaan, Zhwandoon and Khwonkey) and dailies (Anees, Islaah, and Badakhshan) before he migrated to Pakistan. He has authored two volumes entitled, "Quran Shenaasy" (knowing the holy Quran) and "Feqeh Islami Wa Qanoon e Gharb." (Islamic Fiqh and Western Law). The total number of articles he has written is 1500 and he was given the academic title of Professor for his hard work.

After the emergency Loya Jirga, he was appointed as the Vice President of Transitional Government. He was also the Director of the Constitutional Drafting Commission.

H.E. Mr. Shahrani knows Pashto, Dari, Uzbek, Arabic and English, and has delivered speeches in English and Arabic in many conferences.
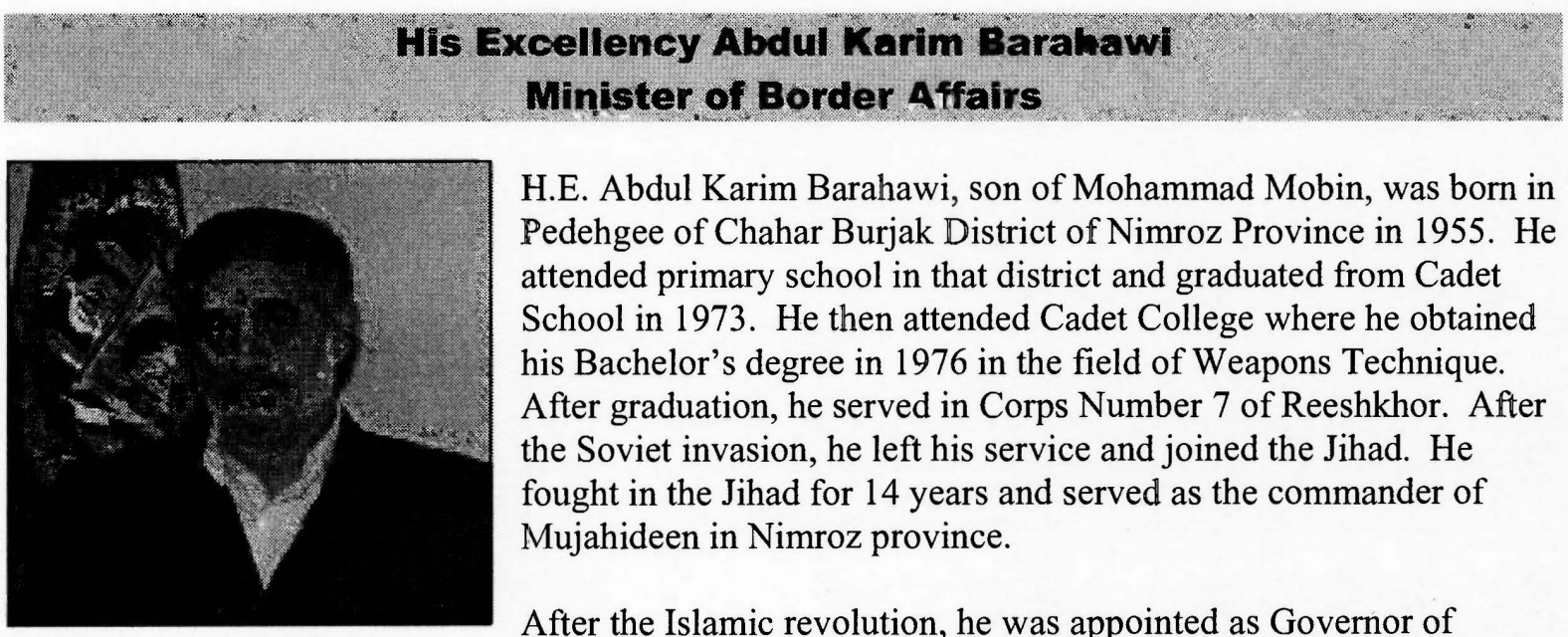

H.E. Abdul Karim Barahawi, son of Mohammad Mobin, was born in Pedehgee of Chahar Burjak District of Nimroz Province in 1955. He attended primary school in that district and graduated from Cadet School in 1973. He then attended Cadet College where he obtained his Bachelor's degree in 1976 in the field of Weapons Technique. After graduation, he served in Corps Number 7 of Reeshkhor. After the Soviet invasion, he left his service and joined the Jihad. He fought in the Jihad for 14 years and served as the commander of Mujahideen in Nimroz province.

After the Islamic revolution, he was appointed as Governor of Nimroz province and the Commander of the 4th Brigade. During the reign of Taliban, he led the resistance front against the Taliban in that province. After the Taliban were defeated, he was again appointed as the Governor of Nimroz and Commander of $4^{\text {th }}$ Brigade. 


\section{Her Excellency Dr. Masooda Jalal \\ Minister of Women's Affairs}

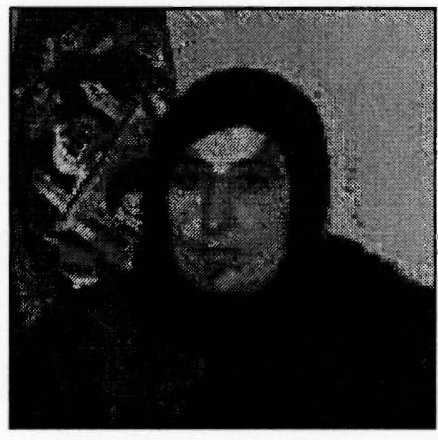

H.E. Dr. Masooda Jalal daughter of Alhaj Tellah Mohammad, was born in Gulbahar of Kapisa district in a middle-class and educated family. She hails from Khesatk of Jerm of Badakhshan. She studied primary and secondary school in Gulbahar High School. In 1982, she graduated from Rabia-e-Balkhi High School and joined medical school that same year. She earned her degree from Kabul Medical Institute in 1988. Soon after in 1989, she started her service as an ear doctor for Maiwand Hospital and then was appointed to the Mental Health Hospital. From 1993 to 1995, she was the Women's Right Director in a women's organization and was a member of the Children's Department of Kabul Medical Institute. She served as a doctor in Ataturk Hospital. In 1996, she began work for UNHCR and afterwards, she served as the Health Advisor for the World Food Programme in Afghanistan as well as a National Program Officer with that organization.
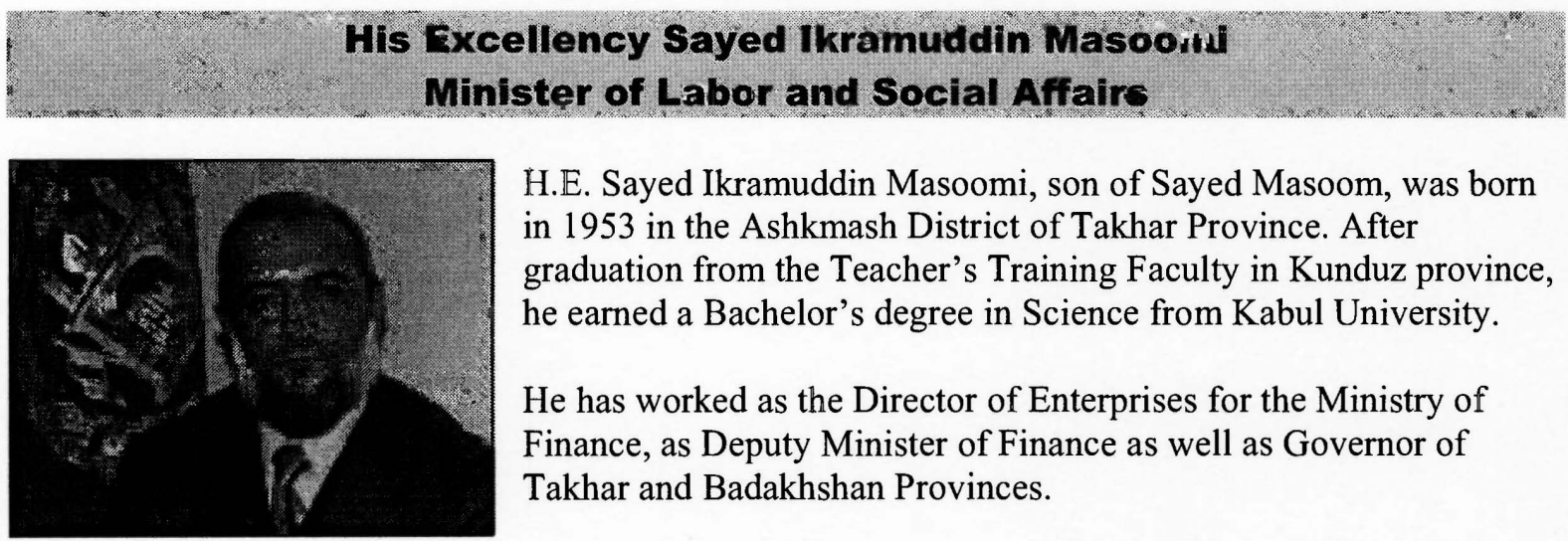

H.E. Sayed Ikramuddin Masoomi, son of Sayed Masoom, was born in 1953 in the Ashkmash District of Takhar Province. After graduation from the Teacher's Training Faculty in Kunduz province, he earned a Bachelor's degree in Science from Kabul University.

He has worked as the Director of Enterprises for the Ministry of Finance, as Deputy Minister of Finance as well as Governor of Takhar and Badakhshan Provinces.
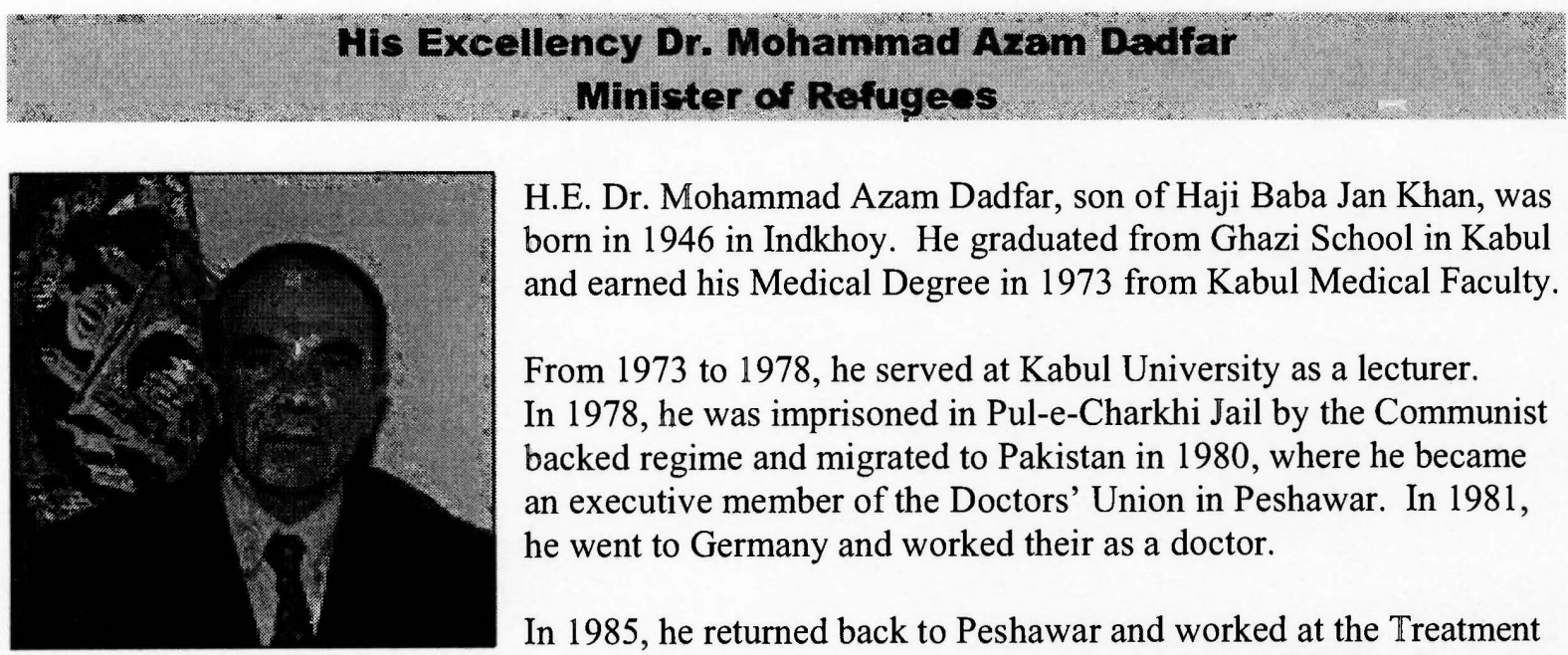

H.E. Dr. Mohammad Azam Dadfar, son of Haji Baba Jan Khan, was born in 1946 in Indkhoy. He graduated from Ghazi School in Kabul and earned his Medical Degree in 1973 from Kabul Medical Faculty.

From 1973 to 1978 , he served at Kabul University as a lecturer. In 1978, he was imprisoned in Pul-e-Charkhi Jail by the Communist backed regime and migrated to Pakistan in 1980, where he became an executive member of the Doctors' Union in Peshawar. In 1981, he went to Germany and worked their as a doctor.

In 1985, he returned back to Peshawar and worked at the Treatment and Research Center of Mental Disorders for Afghans in Peshawar. From 1996 to 1998, he pursued advanced courses for a certificate program in Petersburg, Germany. H.E. Dr. Dadfar speaks Pashto, Dari, Uzbek, German and English and also knows some Turkish. 


\section{Her Excellency Sediqa Balkw \\ Minister of Martyes and Disabled}

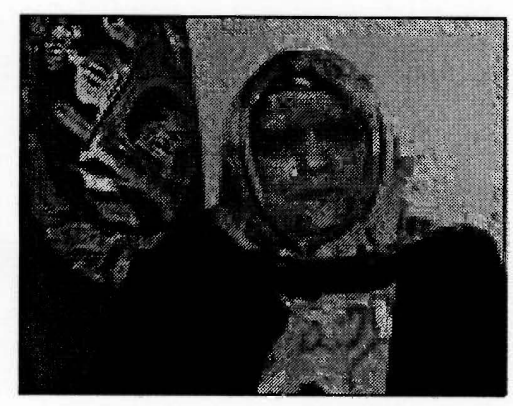

H.E. Sediqa Balkhi, daughter of Sayed Ismaeelm, was born in 1946 in a religious and educated family. She earned a bachelors degree in Islamic Studies. She also followed religious studies in Iran. Besides teaching and working as a manager, she was involved in the antiSoviet invasion movement through publishing articles and holding several seminars. She has made endeavors for providing the young generation of Afghan refugees with education and providing the vulnerable women and girls with business skills.
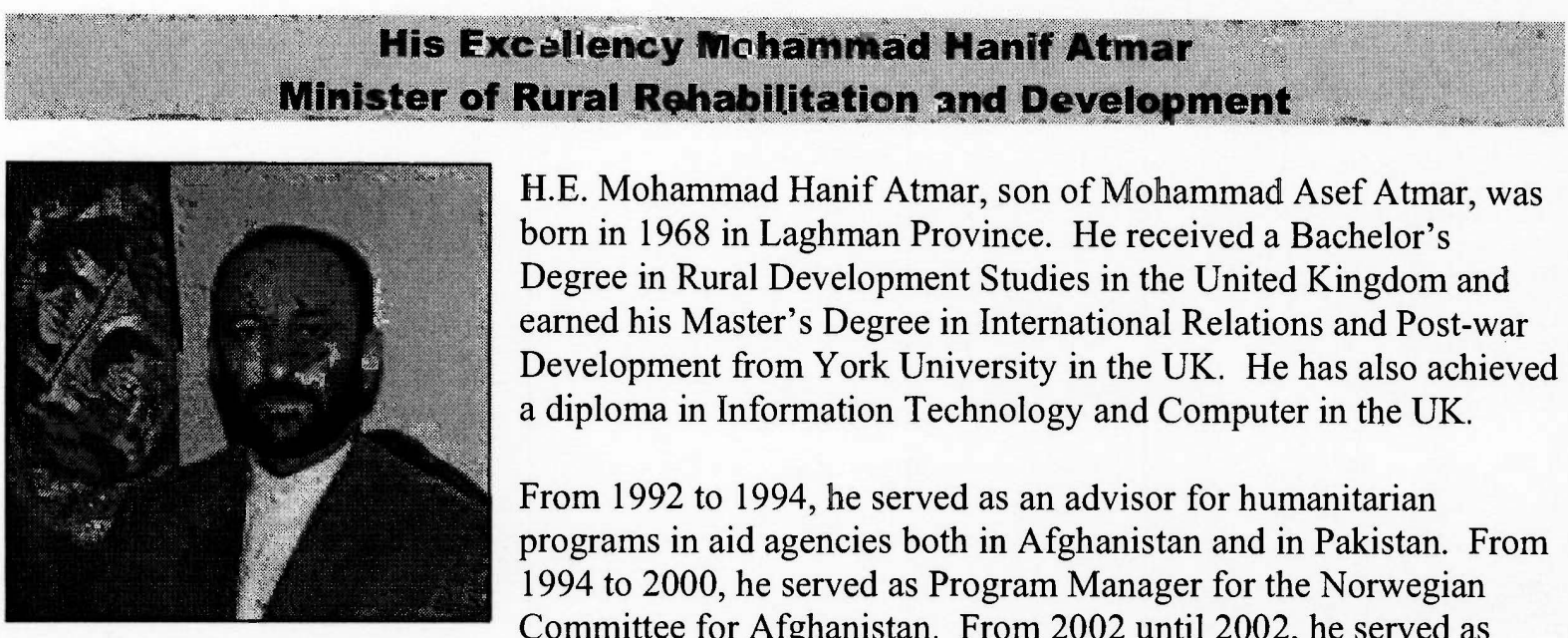

H.E. Mohammad Hanif Atmar, son of Mohammad Asef Atmar, was born in 1968 in Laghman Province. He received a Bachelor's Degree in Rural Development Studies in the United Kingdom and earned his Master's Degree in International Relations and Post-war Development from York University in the UK. He has also achieved a diploma in Information Technology and Computer in the UK.

From 1992 to 1994, he served as an advisor for humanitarian programs in aid agencies both in Afghanistan and in Pakistan. From 1994 to 2000, he served as Program Manager for the Norwegian Committee for Afghanistan. From 2002 until 2002, he served as Deputy Director General of the International Rescue Committee.

In 2002, he was appointed as Minister of Rural Rehabilitation and Development in the Transitional Government.

H.E. Mr. Atmar has authored many books, including "Development of Non-Governmental Organizations in Developing Countries" and "From Rhetoric to Reality, " both published in the UK. He has also authored books entitled, "Humanitarian Aid, War and Peace in Afghanistan: What to Learn,?" "Politics and Humanitarian Aid in Afghanistan and its Aftermath for the People of Afghanistan," and "Afghanistan or a Stray War in Afghanistan." He has also written numerous analytical articles on humanitarian aid in the rehabilitation of Afghanistan. Mr. Atmar is fluent in Dari, Pashto, English and Urdu. 


\section{His Excellency Habibullah Qaderi}

Minister of Anti-Narcotics

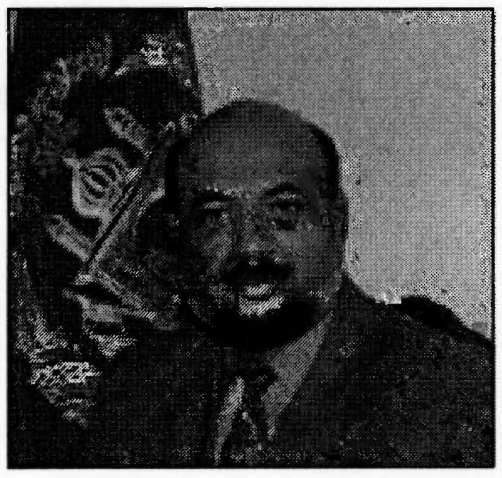

H.E. Habibullah Qaderi, son of Haji Ahmad Qaderi graduated from Ahmad Shah Baba High School in Kandahar and earned his Bachelor's degree in Mechanical Engineering from India.

He worked for a period of 12 years with UNHCR and was a lecturer at Nebraska University, where he was in charge of administering the TOEFL test. He also served as an engineer in a Pakistani company in Karachi.

Since 2002, he has served as the Head Advisor of the Ministry of Refugees' Affairs and a member of the Tri-lateral Commission of Afghanistan, Iran and the UN. He has also been the Director of the Councils of Advisory Groups of Returnees and Displaced People.

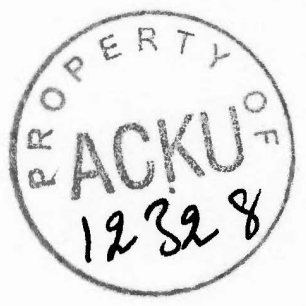

